\title{
Leadership and Natural Resource Management: Linkages to the Persistence of Oil-related Conflicts in Nigeria's Niger Delta
}

\author{
Kialee Nyiayaana*
}

\begin{abstract}
This paper explores the relationship between leadership and natural resource management and the persistence of oil-related conflicts in Nigeria's Niger Delta. It adopts the process theoretical approach to leadership. The key argument is that the space for conversations between leaders and the people of the Niger Delta in the management of oil resources has been historically restrictive in favour of leaders. This accounts for the highly skewed oil ownership and distributive structures that undermine the security needs of the people. Yet, the destructive consenting behaviour of the people shapes peacebuilding process and outcomes in ways that reinforce structures of insecurity and violence in the region.
\end{abstract}

\section{Introduction}

The post-Cold War period has seen a renewed interest in the study of the relationship between natural resource endowment and violent conflict especially with the rise in civil wars and rebellion. Paul Collier's provocative greed and grievance theory, which suggests that the motivations to loot natural resources for private gains rather than justice seeking underpin civil war in post-Cold War Africa, opened the floodgate for other studies. ${ }^{1}$ Some of these studies support, ${ }^{2}$ refine $^{3}$ or completely reject the greed and grievance proposition. ${ }^{4}$ In much of this literature, the role of leadership has, however,

\footnotetext{
1 Collier, Paul (1999), 'Doing Well out of War'. Paper prepared for Conference on Economic Agendas in Civil War. London, April 26-27, pp. 1-16

2 Le Billon, P. (2001), 'The Political Ecology of War: Natural Resources and Armed Conflicts'. Political Geography, Vol. 20, Issue 5. pp. 561-584; Le Billon, Philippe (2012), Wars of Plunder: Conflicts, Profits and the Politics of Resources (New York: Columbia University Press) ${ }^{3}$ Mueller, John (2000), 'The Banality of 'Ethnic War', International Security, Vol. 25, No.1. pp. 4270

${ }^{4}$ Cramer, C (2002), 'Homo Economicus Goes to War: Methodological Individualism, Rational Choice and the Political Economy of War'. World Development, Vol. 30, No.11. pp. 1845-1865;
} 
been neglected. Using Nigeria, which has been confronted with oil wars since the mid 1960s as a point of departure for analysis, this study interrogates the linkages between leadership and natural resource management and the persistence of oil-related conflicts in the oil-rich Niger Delta. It adopts the process-based perspective to leadership, which emphasises mutuality of influence between leaders and followers to deal with a common situation and raises three key questions. How do leaders and the people of the Niger Delta interact to manage land and oil competing interests in the region? What is the nature of leadership styles adopted by leaders in responding to the conflict in the Niger Delta? How do the local populations in the Niger Delta respond to leaders and oil conflicts in the region? Together, these questions raise the need to examine a key proposition. The persistence of oil-based violent conflicts in the Niger Delta is rooted in the exclusionary nature of leadership in Nigeria. Historically, the space for conversations and dialogue between leaders and local people to resolve resource conflict in the Niger Delta has been restricted to the former. This in part accounts for a highly skewed oil ownership structures such as the Petroleum Decree of 1969 that are disincentive to durable peace in the region.

This paper is structured into seven main sections. The first is the introduction. The second reviews studies on natural resource and conflict. The third interrogates the concept of leadership, highlighting different interpretations and their conceptual inadequacies. The fourth examines the management of oil competing interests in the Niger Delta, showing how the exclusionary nature of the leadership process in relation to the formulation and implementation of oil control policies engenders oil conflict in the Niger Delta. Section five analyses leadership style and responses to local demands for inclusionary oil control policies and equity in the distribution of oil benefits. The sixth section examines followership behaviour and their implications for the persistence of oil-related conflicts in the region while the last is the conclusion.

Obi, Cyril (2013), Oil as the 'Curse' of Conflict in Africa: Peering through the Smoke and Mirrors. In Rita Abrahamsen, ed., Conflict and Security in Africa (Rochester, New York: James Currey) Abramhamsen, Rita, ed., (2013), Introduction: Conflict and security in Africa. In Rita Abrahamsen, ed., Conflict and Security in Africa (Rochester, New York: James Currey) 


\section{Natural Resources and Civil War: A Review of Extant Literature}

The link between natural resource endowment and violent conflicts has generated robust debates among scholars since the end of the Cold War. It has been argued, for instance, that the post-Cold War period is characterised by new wars. $^{5}$ The main contention here is that natural resource predation by rebel groups as a means of funding war efforts contrasts sharply with conventional warfare, which is organised, sponsored and fought by regular state armies. ${ }^{6}$ Historically and empirically, the new war hypothesis is inconsistent with reality. When the new war thesis is placed within the context of European imperialism and conflicts in Africa and Asia where natural resource plundering and violence were mutually reinforcing and constitutive, it loses both historical and analytical appeal. ${ }^{7}$ In this regard, the distinction between the so-called new wars and old wars is conceptually misleading.

There is also the greed and grievances theory, which emphasises that rebels see war as an opportunity to loot natural resources for material gains rather than the pursuit of ideologically-driven collective political agenda. The opportunity to loot natural resources, therefore, acts as an incentive for war. ${ }^{8}$

${ }^{5}$ Kaldor, Mary (1999), New and old wars: Organized Violence in a Global Era (Palo Alto, CA: Stanford University Press; see also Kaldor, Mary (2013), 'In Defence of New Wars'. Stability, Vol. 2, No.1. pp. 1-16

${ }^{6}$ Ibid

7 Alao, Abiodum and Olonisakin, Funmi (2000), 'Economic Fragility and Political Fluidity: Explaining Natural Resources and Conflicts'. International Peacekeeping, Vol. 7, No. 4, pp 23-36; Kalyvas, Stathis, N. (2001), 'New' and 'Old' Civil Wars: A Valid Distinction'? World Politics, Vol. 54, No.1.pp. 99-118

8 Collier, Paul. and Anke, Hoeffler (1998), 'On Economic Causes of Civil War'. Oxford Economic Papers, Vol. 50, No. 4, pp. 563-573; Keen, David (1998), The Economic Functions of Violence in Civil wars (Oxford: Oxford University Press); Collier 1999; Collier, Paul. and Anke, Hoeffler (1998), 'On Economic Causes of Civil War'. Oxford Economic Papers, Vol. 50, No. 4, pp. 563-573; Collier, Paul and Anke, H. (2001), 'Greed and Grievance in Civil War' Washington, DC: World Bank; Le Billon 2001; Le Billon, 2012; Berdal, Mats. \& Malone, David M. (2000), Greed and Grievance: Economic Agendas in Civil Wars (Boulder, CO: Lynne Rienner); Ikelegbe, Agustine (2005), 'The Economy of Conflict in the Oil Rich Niger Delta Region of Nigeria' Nordic Journal of African Studies Vol. 14, No. 2, pp. 208-234; Lujala, Paivi (2010), 'The Spoils of Nature: Armed conflict and Rebel Access to Natural Resources'. Journal of Peace Research, Vol. 47, No. 1, pp. 1528. 
Greed and grievance theory can be contested on several grounds. First, the cause of resource-based conflicts including its sustenance and prolongation cannot be effectively explained from an economic perspective. It is a consequence of more complex factors. ${ }^{9}$ Yet, not all post-Cold War civil wars are fought for economic reasons, for example, Somalia, Rwanda, Burundi and Sudan. ${ }^{10}$ Second, the greed theoretical explanations are often divorced from their specific and larger historical, political and social context of the conflict and this has been further complicated by the tendency amongst its proponents to generalise their findings. ${ }^{11}$ Lastly, the greed and grievance theory has a strong neoliberal ideological character and agenda, what Claude Ake calls social science as imperialism. ${ }^{12}$

Another version of the greed perspective is the resource curse theory. This theory suggests that natural resource abundance triggers violence and conflicts. More specifically, scholars have highlighted the risks that natural resource poses to political and economic development in terms of hindering the development and consolidation of democracy,13 weakening of state capacity to levy and collect tax ${ }^{14}$ and the engendering of political corruption with negative implications for industrial development. ${ }^{15}$ Statistically, countries like Nigeria, Angola, Sudan, Chad, Equatorial Guinea, DRC, Sierra Leone, Cambodia and Liberia amongst others have experienced varied forms of

\footnotetext{
${ }^{9} \mathrm{Obi}, 2013$

${ }^{10}$ Herbst, J (2000), 'Economic Incentives, Natural Resources and Conflict in Africa'. Journal of African Economies, Vol. 9, No. 3. pp. 270-290

${ }^{11}$ Peters, Krijn and Richards, Paul (1998), "Why We fight': Voices of Youth Combatants in Sierra Leone', Africa, Vol. 68, No. 2, pp. 183-210; Alao, Biodum and Olonisakin, Funmi (2000); Cramer, C (2002); Obi Cyril (2013); Obi Cyril (2014a), 'Oil and Conflict in Nigeria's Niger Delta Region: Between the Barrel and The Trigger'. The Extractive Industry and. Society, Vol. 1, Issue 1, pp. 147153

${ }^{12}$ Ake, Claude (2000), Social Science As Imperialism (Ibadan: Ibadan University Press, 2nd edition) Kalyvas, Stathis N. 2001; Abramhamsen, Rita 2013

${ }^{13}$ Ross, Michael L (2001), 'Does Oil hinder Democracy?' World Politics, Vol. 53, Issue 3, pp.325361; Ross, Michael L (2012), The oil curse: How Petroleum Wealth Shapes the Development of Nations (Princeton University Press); Andersen and Aslaksen, 2013

${ }^{14}$ Auty, R.M. (2001), Resource Abundance and Economic Development. Oxford: Oxford University Press; Torvik, Ragnar (2002), 'Natural Resources, Rent Seeking, and Welfare'. Journal of Development Economics, Vol. 67, issue 2, pp. 455-470 15 Rosser, A. (2006), 'The Political Economy of the Resource Curse: A Literature Review'. Working Paper 268. Brighton: Institute of Development Studies.
} 
violent conflicts that have been directly linked to natural resources. ${ }^{16}$ These countries are also characterised by mass poverty, chronic unemployment, diseases, hunger and high mortality rate despite huge oil revenue they generate. These paradoxes tend to suggest that mineral producing countries indeed suffer from resource curse or what is also called the Dutch Disease. ${ }^{17}$

A key limitation of the resource curse theory, however, is that the statistical relationship between natural resource abundance and underdevelopment in oil-endowed states is deterministic. It does not explain causality. ${ }^{18}$ These limitations notwithstanding, the resource curse/greed theory has significantly influenced peace and natural resource governance policies. The Extractive Industries Transparency Initiative (EITI) and the Kimberly Process Certification Scheme (KPCS), which came into existence in 2002 and 2003 respectively, are key examples. The KPCS is a global governance response to the illicit trade in diamonds by rebels, the so-called conflict diamonds. The EITI policy on the other hand, focuses on transparency and accountability in the mining and production of minerals such as oil. To some extent, KPCS has been effective in that it has contributed to the reduction of the flow of conflict diamonds into the international market. ${ }^{19}$ However, by targeting 'greedy rebels', and war situations only, rather than the structural roots of rebellion, the Kimberly Process reflects a reactive rather than preventive policy measure ${ }^{20}$ Similarly, in the case of EITI, tackling the problem of corruption in Nigeria's oil industry, for instance, may not automatically resolve the intergenerational grievances in the Niger Delta over structural expropriation of land and oil resources of the people and the negative social impacts associated with oil extraction processes. This is because the adoption of EITI

16 Alao, Abiodum (2007), Natural Resources and Conflict in Africa: The Tragedy of Endowment (Rochester: University of Rochester Press); Yates, Douglas A. (2012), The Scramble for African Oil: Oppression, Corruption and War for the Control of Africa's Natural Resources (London: Pluto Books)

17 Karl, Terry Lyn (1997), The Paradox of Plenty: Oil Booms and Petro-States (Berkeley, CA: University of California Press)

18 Morrison, Kelvin M (2013), 'Whither the Resource Curse?' Perspectives on Politics, Vol. 11, Issue 4, pp. 1117-1125; Obi (2014a)

${ }^{19}$ Andrews, Anne.E. (2006), 'Diamond is Forever: De Beers, the Kimberely Process, and the Efficacy of Public and Corporate Co-regulatory Initiatives in Securing Regulatory Compliance Note'. South Carolina Journal of International Law and Business, Vol. 2, No. 1

${ }^{20}$ Kabemba, C. (2010), 'The Kimberley Process and the Chiadzwa Diamonds in Zimbabwe: Challenges and Effectiveness'. Perspectives, Report of the Heinrich Böll Foundation, No. 3.10 
as a key policy measure for dealing with 'the resource curse in Nigeria and other resource-rich African countries is based on a particular reductionist conception of the nature of the problem that also depoliticises it'.21

The point then is that since these policies are based on wrong assumptions of the resource curse/greed approaches to resource-based conflicts, they are more likely to fail with implications for the continuation of conflicts. Indeed, the conflict and underdevelopment crises, which confront many oil-producing countries, are not consequences of 'resource curse'. Rather, they are the 'curse' of national policies. ${ }^{22}$ This is because 'political decisions do matter, and they mediate the apparent relationship between resource wealth and outcomes like political stability or economic performance'.23 Consequently, policies that leaders adopt in relation to natural resource management may have serious implications for social justice and peace. Therefore, a fruitful analysis of the natural resource-conflict trap will have to go beyond corruption and interrogate the complex social, political and economic relations that develop among people in natural resource extraction processes and how these relations are managed to reconcile conflicting interests and the cause of conflicts. For some, the tragedy of natural resource endowment in Africa lies in governance failure and, therefore, neither natural resource abundance nor its criminal plundering by warlords is sufficient to explain the outbreak of violent conflicts in the continent. ${ }^{24}$

But, as noted above, the claim can also be made that state's policies mediate relations between leaders and the people in terms of who should have what access, how and why, to particular social, economic and political opportunities in a social formation including the benefits of natural resources. Therefore, it can be argued that governance defined as laws, policies, institutions and their regulatory capacity 25 are to a large extent, a reflection of the outcomes of the nature of interactions between the people and the leaders, raising a key issue

${ }^{21}$ Idemudia, U. (2010), 'The Extractive Industries Transparency Initiative (EITI) in Nigeria: Sifting Rhetoric From Reality'. Perspectives, Report of the Heinrich Böll Foundation, No. 3.10, p. 12

${ }^{22}$ Saad-Filho, Alfredo and Weeks, John (2013), 'Curses, Diseases and other Resource Confusions'. Third World Quarterly, Vol. 34, Issue 1, pp. 1-21

${ }^{23}$ Dunning, Thad (2005), 'Resource Dependence, Economic Performance, and Political Stability'. Journal of Conflict Resolution, Vol. 49, No.4, pp. 451-482

${ }^{24}$ Alao (2007)

${ }^{25}$ Ibid 
for leadership in the management of natural resources and its implications for resource-based conflicts. Botswana's success case in the management of diamond with no record of violent conflicts to-date tends to suggest a key role for effective leadership. ${ }^{26}$

To-date, however, focused investigation of the role of leadership in resource conflict is neglected in the analysis of natural resource and conflict and more broadly, conflict and security. ${ }^{27}$ Even those who examine the crisis of peacebuilding in Africa from a leadership perspective, ${ }^{28}$ often exclude followers, an approach that reinforces the leader-centric explanation and understanding of leadership rather than process. The foregoing, therefore, draws attention to the need for a reconceptualisation of leadership in process terms, ${ }^{29}$ which this study employs to understand the linkage between leadership and resource conflicts in the Niger Delta. It raises questions about how leaders and local population in the Niger Delta interact to resolve resource conflicts and build peace in the region, not least because the Isaac Adaka Boro's 1966 rebellion was a continuation of the historical struggle against social and political marginalisation of the Niger Delta people, which dates back to the colonial times. ${ }^{30}$ In other words, resource-based conflicts have become endemic in the Niger Delta despite efforts by successive leaderships in Nigeria since political independence in 1960 to find lasting solutions to it.

26 Sebudubudu, David and Botlhomilwe, Mokganedi Zara (2012), 'The Critical Role of Leadership in Botswana's Development: What Lessons'. Leadership, Vol. 8, No. 1; Diallo, P. (2014), 'Mining, Governance and Stability in Africa: Comparative Case Studies of Guinea, Botswana and Sierra Leone'. Paper presented at the first Annual Conference of the African Leadership Centre's Leadership and Society Series, at the African Leadership Centre, Nairobi, June 23-25

27 Gormley-Heenan, Cathy (2006), 'Chameleonic Leadership: Towards a New Understanding of Political Leadership During the Northern Ireland Peace Process'. Leadership, Vol.2, No. 53; p.54; Olonisakin, 2015, p. 122

${ }^{28}$ See Cartwright, John R. (1983), Political Leadership in Africa (New York: St. Martin's Press). Rothberg, Robert. I. (2003), 'The Roots of Africa's Leadership Deficit'. Compass: A Journal of Leadership, Vol. 1, No 1. pp. 28-32; Read, James H. and Shapiro, Ian (2014), 'Transforming Power Relationships: Leadership, Risk, and Hope'. American Political Science Review, Vol. 108, No. 1. pp. 40-53; Rothberg, Robert. I. (2014), 'The Need for Strengthened Political Leadership'. The ANNALS of the American Academy of Political and Social Science, Vol. 652, No. 1, pp. 238-256

29 Olonisakin, 2015, pp.131-132

30 Tamuno, Tekena.N. (2011), Oil Wars in the Niger Delta. 1849-2009 (Ibadan: Stirling-Horden Publishers), pp. 171-191 
Persistent oil-related conflicts in the Niger Delta, therefore, present an interesting case for interrogating the role of leadership for two main reasons. First, unlike Angola, Sierra Leone, Liberia, the Democratic Republic of Congo amongst others, which are all cases of prolongation of conflicts in which diamond and Timber influenced the armed rebellion as secondary conflict dynamics, ${ }^{31}$ the Nigerian case is primarily rooted in the contestations over the ownership of land and oil between Niger Delta communities and the Nigerian state for over four decades today. Second, although Botswana contrasts sharply with Nigeria as a success case, both countries ultimately highlight the centrality of leadership in the natural resource-conflict nexus debate in Africa. Accordingly, what lessons can we learn from leadership in the Niger Delta experience within the context of natural resource-conflicts conundrum in Africa?

\section{Conceptualising Leadership}

Leadership is a concept that has defied precise meaning principally because of its complexity. This complexity stems, in part, from its historical evolution, disciplinary orientations of scholars and practitioners, cultural and class differences, professional experiences and divergent interests. As a consequence, therefore, what exist in the literature are multiple definitions. In an attempt, to explain what leadership is and what it is not, existing definitions have been summarized into four main classifications: leadership as position; leadership as person; leadership as the achievement of outcome and leadership as process. ${ }^{32}$ These four components are subjected to a critical analysis to clarify the notions of leadership as follows.

Defining leadership as position tends to imply that anyone who occupies a position of authority and power automatically exercises leadership. The head of an organisation is thus perceived as a leader by virtue of his or her position. The positional approach tends to conflate headship with leadership, both of which are qualitatively different. In headship, there is a vertical and hierarchical structuring of relationships amongst people in a group process in

\footnotetext{
${ }^{31}$ Malaquias, A. (2007), Rebels and Robbers: Violence in Post-colonial Angola (Uppsala: Nordiska Afrikainstitutet)

32 Grint, Keith (2010), Leadership: A Very Short Introduction (Oxford: Oxford University Press), pp 4-5; Northouse, Peter .G. (2013), Leadership: Theory and Practice (SAGE: Thousand Oaks, California), pp. 4-7
} 
which influence is unidirectional and top-down. Consequently, policies and decisions often flow or are expected to flow directly from the top, suggesting that they are rarely the result of exchanges and dialogues between the leader and followers, and which in most cases must be complied with. ${ }^{33}$ Clearly, the leader-follower relationships are not free from power and its demonstration. ${ }^{34}$ Nevertheless, not all power relationships involve leadership, not the least, because leadership is about the management of meaning. Followers grant power to the leader to interpret reality and define meaning for them in expectations of an outcome that satisfies their needs. Yet, followers are indispensable in achieving these outcomes. ${ }^{35}$

Moving from the positional approach, the trait perspective is also insightful. From a psychological standpoint, individual personality traits and characteristics have also been used as the basis for distinguishing between a leader and followers ${ }^{36}$ Referred to as the 'Great Man' theory, which emerged in early $20^{\text {th }}$ century, the key assumption is that some people are born leaders and others followers precisely because of their psychological traits such as charisma and physical appearances. Thus, the Tutsis in Rwanda were considered leaders by their German and Belgium colonial overlords precisely because they (the Tutsis) were said to be naturally intelligent, thin and tall compared to their Hutu counterparts who were sturdy in physical appearance. While certain traits and competences may be required for effective leadership as Warren Bennis (1990) has argued, a key limitation of identifying natural traits and abilities with leadership is that it underlies the assumptions that traits matter all situations and contexts. The trait approach is also exclusionary in that some people like women are easily excluded from assuming and playing leadership role based on gender differentiation.

\footnotetext{
${ }^{33}$ Allport, Floyd Henry (1924), Social Psychology (Boston: Houghton Miffin)

${ }^{34}$ French, John R. P. and Raven, Bertram (1959), 'The Bases of Social Power'. In D. Cartwright, ed., Studies of Social Power. Ann Arbor, MI: University of Michigan, Institute for Social Research. pp. 262-268; Cooper, Andrew Fenton and Higgott, Richard A.. \& Nossal, Kim Richard (1991), 'Bound to Follow? Leadership and Followership in the Gulf Conflict'. Political Science Quarterly, Vol. 106, No. 3. p. 396

${ }^{35}$ Smirch, Linda and Morgan, Gareth (1982), 'The Management of Meaning'. Journal of Applied Behavioural Science, Vol. 18, No. 3, p. 258

${ }^{36}$ Peters, Thomas J. and Waterman, Robert. H. (1982), In Search of Excellence: Lessons From America's Best-run Companies (New York: Warner Books); Kirkpatrick, Shelley A and Locke, Edwin A. (1991), 'Leadership: Do Traits Matter'. Academy of Management Executive Vol. 5, Issue $2, \mathrm{p} 48$
} 
Another school of thought sees leadership as synonymous with achieving results or goals by a leader. ${ }^{37}$ From this perspective, leadership occurs only when a leader achieves results or set goals. Goals or results achievement is indeed an indispensable measure of leadership. However, somewhat related to the person-based approach, there is the tendency to always focus on the individual leader and ignore followers in the achievement of a group's goal. Two inherent weaknesses are immediately apparent in the result-based perspective. The first is that placing responsibility of achieving results on the leader alone ignores the process, and indeed, the visibility and contributions of other people within the group in attaining a collective goal. Second, when the leader fails, 'the followers would scapegoat him or her and thus cleanse themselves of any responsibility'. ${ }^{38}$ In this way, result-based notions of leadership not only exalt the leader to the level of a thin god but also perpetuate followership alienation in the leadership process. This is because followers are rarely challenged to own up to their responsibility for success or failure.

Finally, leadership has also been conceived from the process perspective. The process approach sees leadership as the reciprocal exchange of influence between a leader and followers toward achieving a shared goal. ${ }^{39}$ The emphasis here is that there is a correspondence between the leader and followers in the exchange of ideas to meet the needs of a common situation. As a sociological process, therefore, the leader and followers are involved in dynamic back and forth interactions directed toward addressing the need of a particular situation. Yet, finding solutions to the current problem is not an end in itself. This is because a new solution may give birth to a new situation especially because society is constantly in flux. This suggests that a leader today might become a follower tomorrow and vice versa because of the demands, complexities and challenges of the new situation. This is not to suggest, however, that leadership is slippery. Instead, the argument is that:

${ }^{37}$ Davies, R.C. (1942), The Fundamentals of Top Management (New York: Harper)

${ }^{38}$ Grint, (2010), p. 9

${ }^{39}$ Murphy, Albert J. (1941), 'A Study of the Leadership Process'. American Sociological Review Vol. 6, No. 5, pp. 674-687; Burns, J. M. (1978), Leadership (New York: Harper \& Row); Bass, B. M. (1990), Handbook of Leadership (New York: The Free Press), Grint, (2010), Leadership: A very Short Induction; Olonisakin, Funmi 2015, ' Reconceptualising Leadership for Effective Peacemaking' 
'Leading alternates with following solutions are new stages in the situation preparing the way for other solutions, which in turn call for new types of leadership to secure new ends'. ${ }^{40}$

The above analyses have shown that each perspective has its own analytic and practical utility. However, this study adopts the process theoretical approach because it is particularly relevant in conflict situations in the developing countries where democratic institutions are evolving and weak. Criticizing the result-based approach to leadership, some scholars have has argued that the major limitation of peacebuilding interventions in Africa is they overly focus on results or the achievement of quick gains rather process; and the logic of this approach has seen the frequent relapse into conflicts in the continent. ${ }^{41}$ Furthermore, it is noted that the trait-based approach offers no sustainable solutions to conflicts either, because situations of conflicts are rapidly changing both in causation and means of combat that require creative responses in specific situations rather than individual traits. ${ }^{42}$ Terrorist tactics, such as the use of female suicide bombers by the Boko Haram group in Nigeria is unknown to Nigerian culture in the prosecution of violent conflicts. But this has come to stay in Nigeria today. Following the limitations of the traits and result-based approach, it must be emphasized that contexts of conflict are better understood and peacebuilding better enhanced by defining leadership as process. ${ }^{43}$ Studying the traits of a person, which distinguish them as a leader does not offer a sustainable way of defining leadership particularly in conflict situations'. To put it differently, 'defining leadership as process thus allows us to capture the dynamism of this construct in contexts of conflict and peacemaking, which are especially characterised by rapid change' ${ }^{44}$

\section{The Contexts of Oil Conflicts in the Niger Delta}

The Niger Delta region of Nigeria has a population of about 31.2 million people and comprises mainly ethnic minority groups such as the Andoni, Efik, Ibibio,

\footnotetext{
${ }^{40}$ Murphy, (1941), p. 677

${ }^{41}$ Olonisakin, (2015), p.128

${ }^{42}$ Ibid p.131

${ }^{43}$ Ibid p. 131

${ }^{44}$ Ibid p. 132
} 
Ijaw, Ikwerre, Itshekiri, Kalabari, Ogoni, and Urhobo.45 It is endowed with abundant natural gas and crude oil and therefore, the hub of oil extraction business in Nigeria and home to several Multinational Oil Corporations (MNOCs). These companies include: the Anglo/Dutch Shell Petroleum Development Company (SPDC also known as Shell), Mobil, Chevron, Elf and Texaco. Shell holds the largest share of oil production quota in the region. ${ }^{46}$

Crude oil was discovered in 1937 in the Niger Delta and its commercial exploitation and export started first in Oloibiri community in 1958 and later in Bomu community in Ogoni the same year. The ascendancy of oil as the main foreign exchange earner in Nigeria beginning from the 1970s has marked very complex relationships between the Niger Delta people, MNOCs and the Nigerian State in several ways. First, while $90 \%$ of Nigeria's national budget is financed from oil revenue derived from the Niger Delta, the people of the region have seen little benefits of oil wealth. In the $21^{\text {st }}$ century, infrastructural development is generally poor in the region. Basic amenities such as electricity, water supply and hospital facilities are out of reach for majority of the people in the region who are also chronically poor. Recent empirical studies rate the Niger Delta above national average in socio-economic index computations of poverty and unemployment. ${ }^{47}$ However, by some accounts, an estimated US $\$ 932$ billion of oil revenue has been generated from the region between 1960 and 2012.48 The Niger Delta thus enjoys the contradiction of being the richest and poorest, a compounded paradox of a sort. 49

Second, insensitive and reckless oil production operations and practices of oil companies have left the Niger Delta environment highly degraded since 1958.

${ }^{45} \mathrm{Kuku}$, Kingsley (2013), 'Assessing the Dynamics and Sustainability of the Niger Delta Amnesty Programme' A presentation made by Hon. Kingsly Kuku to Nigerians in the Diaspora'. (Abuja: Amnesty Office)

${ }^{46}$ Obi, Cyril (1997), 'Globalisation and Local Resistance: The Case of the Ogoni versus Shell'. New Political Economy, Vol.2 No.1, pp. 137-148

47 United Nations Development Programme (2006), 'Niger Delta United Nations Human Development Report of the United Nations Development Programme'. UN House (Abuja: Nigeria)

${ }^{48}$ Naanen, Ben and Tolani, Patrick (2014), 'Private gain public disaster: Social context of illegal oil bunkering and artisanal refining in the Niger Delta'. Report of the Niger Delta Environment and Relief Foundation (NIDEREF) (Port Harcourt: NIDEREF), p. 26

${ }^{49}$ Naanen, Ben (1995), 'Oil-producing Minorities and the Restructuring of Nigerian Federalism: The Case of the Ogoni people'. The Journal of Commonwealth \& Comparative Politics, Vol. 33, No. 1, pp. 46-78 
Recently, the United Nations Environmental Programme's (UNEP) Report on Shell's activities in Ogoni reveals the extent to which the company has destroyed the ecosystem of the area. ${ }^{50}$ The Report particularly identifies high level of Benzene contamination of underground water in Ogoni and the danger it poses to community well-being especially the risks and vulnerability of the local populations to the diseases of cancer. Underscoring the gravity and severity of Shell's ecological devastations in Ogoni, UNEP Report further notes that it would take 25-30 years of effective remediation efforts to clean up, regenerate and restore the Ogoni environment. ${ }^{51}$

In light of the above, agitation for mutually beneficial structural arrangements for distribution of oil revenue and oil-related opportunities by oil-bearing communities in the Niger Delta has raised issues of effective management of land and oil resources, the larger questions of sovereignty and inclusive citizenship on one hand. ${ }^{52}$ On the other, the demand for the observance and promotion of ecologically sound and sustainable oil production activities that are consistent with international best practices by the local communities has pitted these communities against MNOCs and the Nigerian State whose interests appear to diverge from the local communities. ${ }^{53}$ Negotiating and reconciling these complex, complicated and competing interests of the local communities, MNCOs and the state has raised broader questions about the nature of leadership and leadership process in relation to the management and distribution of natural resource wealth in Nigeria.

\section{Leadership and the Management of Oil competing Interests}

Several indicators of the nature of leadership in Nigeria can be discerned in relation to the management of oil competing interests in the Niger Delta, whether in terms of resource control or fair distribution of oil revenue. Key in this regard, is the exclusionary nature and character of oil control laws. In 1966, Isaac Adaka Boro led the Niger Delta Volunteer Service (NDVS) and declared the Niger Delta area a sovereign republic in a twelve-day revolutionary war. Boro's grievances were premised on the developmental

\footnotetext{
${ }^{50}$ United Nations Environment Programme, UNEP Report, (2011), Environmental Assessment of Ogoniland (Nairobi: United Nations Environment Programme).

${ }^{51}$ Ibid p. 207

52 Ejobowah, John Boye (2000), 'Who Owns the Oil? The Politics of Ethnicity In The Niger Delta of Nigeria'. Africa Today, Vol. 47, No. 1. pp. 29-47

53 Tamuno, Tekena.N. (2011), Oil Wars in the Niger Delta (Ibadan: Stirling-Horden Publishers)
} 
neglect of the Niger Delta and the issue of resource ownership and distribution. However, rather than address the equitable distributional and oil ownership issues raised by Isaac Boro's rebellion in 1966, national leaders acting like biblical Pharaohs instead introduced a series of legislation to effectively dispossess the people of the Niger Delta of any claims and rights to their land and oil resources.

The first legislation in this direction was the Petroleum Decree of 1969, which granted the Nigerian State the sole control and ownership of all petroleum in, under or upon any lands in the country. ${ }^{54}$ It also empowers the state to issue or withdraw oil concession license to any oil companies it deems fit to engage in oil exploration and extraction activity without involving or consulting the oil-producing communities. In essence, in the business of oil production, the people on whose lands crude oil has been found have virtually no role to play. Their interests have been taken for granted as it were in the colonial era. Indeed, structurally, the Petroleum Decree of 1969 was not different from the colonial Minerals Act of 1914, which had vested the power of control and ownership of all mineral resources in Nigeria in the British colonial authorities. Subsequent regulation such as the Land Use Decree of 1978, Oil Pipelines Decree of 1991 and the Petroleum Decree of 1991 only sought to consolidate the stranglehold on oil, both onshore and offshore by the state..$^{55}$ Imposed from above, these laws leave the fate of the local people in the Niger Delta at the mercy of profit-driven MNOCs and a rent-seeking Nigerian state, an approach that differs markedly from other countries such as Botswana.

In the mining of diamond in Botswana, the State or De Beers cannot operate in any community without first consulting and securing the consent of the people even though by law all mineral resources belong to the State. ${ }^{56}$ This structural arrangement has created some sense of shared responsibility and accountability between the local communities and De Beers on one hand, and the state and local communities on the other, in the mining of diamonds with implications for peace. Furthermore, in the distribution of wealth arising from diamond, Botswana's policy is highly inclusive. As at 2007, Botswana's per

\footnotetext{
${ }^{54}$ Somerekun, K. (1995), Perspectives on the Nigerian Oil Industry (Lagos: Amkra Books), p.16

55 Etekpe, A., Y. Ayotamuno, M. Nwala, Y.E. Jumbo, M.C. and K. Kariboro (2010), eds., Conflict management and resolution in Nigeria: The Niger Delta experience (Port Harcourt: Pearls Publishers)

${ }^{56}$ Sebudubudu and Botlhomilwe, (2012)
} 
capita income was US\$5,600 according to the World Bank.57 In fact, a comparative study of 15 African oil and diamond producing countries, shows that Botswana rates higher in distributional policies with benefits of diamond trickling down to the people, and this has had significant implications for fostering peace. ${ }^{58}$ It has also been argued that while Botswana's Diamond is not alluvial and therefore not easily lootable, the participatory nature of leadership, and policies adopted in the management of diamonds matter most in understanding the peaceful nature of Botswana since the 1970s. ${ }^{59}$

In Nigeria, as noted earlier, oil companies are imposed on oil-producing communities through coercive laws. Yet, in deciding who gets what, how and why in terms of distribution of oil revenue, the people are also not part of that decision making process. Consequently, the oil-producing Niger Delta states get only $13 \%$ as their allocation of oil revenue based on the principle of derivation while the federal government receives $87 \%$. This highly skewed distribution of revenue reflects the coercive nature of the leadership process. This has been evident in 'the systematic and progressive reduction in the derivation principle from $45 \%$ to the oil producing region in 1960, $20 \%$ in $1970,2 \%$ in $1975,1.5 \%$ in $1982,1.5 \%$ in $1984,3 \%$ in 1992 and $13 \%$ to date'. 60

But, prior to Nigeria's independence, the derivation principle was $50 \%$. Then, cocoa, cotton and groundnuts produced in Northern and Southern Nigeria respectively were the major sources of national revenue. Consequently, the majority ethnic groups under their respective regional governments enjoyed a high level of fiscal autonomy contrary to what obtains today. Coincidentally, it was also during the period when the majority ethnic groups dominated the political space as Nigeria's presidents that all the draconian legislation targeted at oil resources in the Niger Delta were enacted. It was only in 2010 that Goodluck Jonathan, an indigene of the Niger Delta emerged for the first time as president of Nigeria. It is against these dynamics and familiar patterns of land and oil-related legislation and policies during their regimes that have bolstered the arguments and perceptions that ethnicity and ethnic discriminations underline the politics of differential revenue allocation

\footnotetext{
57 The World Ban cited in Sebudubudu and Botlhomilwe (2012), p. 330

${ }^{58}$ Basedau, Matthias and Wegenast, Tim C. (2009), 'Oil and Diamonds as Causes of Civil War in sub-Saharan Africa: Under What Conditions?' Colombia International, 70, pp. 35-59

${ }^{99}$ Diallo, (2014); Sebudubudu and Botlhomilwe (2011)

${ }^{60}$ Tamuno (2011), p. 6
} 
formula in Nigeria ${ }^{61}$ or what some have aptly described as internal colonialism. ${ }^{62}$ This is because how much share of oil revenue that the Niger Delta states receive from the federal government on the basis of the derivation principle is an important political question to be addressed. It also demonstrates some level of resource autonomy and political inclusion.

However, the failure to effectively translate even the revenue and proceeds derived from oil into material improvements of human conditions in the Niger Delta by leaders at the state and local government levels in the region suggests that it is much more an issue of distribution than ethnicity. Distribution, this study will argue, raises questions of effective leadership rather than ethnicity. Recent data on revenue allocated to states by the federal government suggests that 'between 2004 and 2008, 13 percent revenue allocations to oil-producing states actually translate to 46.99 percent of the total federal allocation to states in the federation'.63 These allocations have been managed by governors who are themselves indigenes of the Niger Delta in the first place. However, benefits of this revenue have not trickled down to the ordinary people in form of improved income, accessibility to clean water and modern infrastructures. As at 2006 'only 27 percent of people in the Niger Delta have access to safe drinking water and about 30 percent of households have access to electricity, both of which are below the national averages of $31.7 \%$ and $33.6 \%$, respectively'.64

Thus, mismanagement of oil revenue has created good life and wealth for few political elites of the region while the local people continue to live in abject conditions of poverty. Thus, for some scholars, 65 it is corruption that is at the root of underdevelopment and endemic violence in the region rather than ethnicity. Again, this paper argues differently. While corruption poses a serious

\footnotetext{
${ }^{61}$ Osaghae, Eghosa. E. (1998), 'Managing Multiple Minority Problems in a Divided Society: The Nigerian Experience'. The Journal of Modern African Studies, Vol, 36, No. 1. pp. 1-24; Tamunu, 2011

62 Naanen, (1995)

63 Ogundiya, Ilufoye.Sarafa. (2011), 'Beyond the Geography of Terrorism and Terror of Geography' Thesis: Corruption and the Development tragedy in the Niger Delta region'. Journal of Developing Societies, Vol. 27, No.1. p. 76

${ }^{64}$ Ibeanu, Okechukwu (2006), 'Civil Society and Conflict Management in the Niger Delta: Scoping Gaps for Policy and Advocacy'. Cleen Foundation Monograph Series, No. 2

${ }^{65}$ Ogundiya, (2011)
} 
threat to peace, ${ }^{66}$ the root cause of corruption is rarely addressed by studies on corruption, creating serious dilemma for policy interventions. A key contention here is that corruption is an important question of leadership. When leaders rarely exchange influence with the people in formulating and implementing policy decisions that affect their daily life, especially in the developing world, there is the tendency for leaders to be less accountable with implications for further centralisation and consolidation of power. Yet, centralisation of power and unaccountability are mutually reinforcing. This, perhaps, accounts for the near total disconnect between leaders and the people at the national, state and local government as well as the local communities in the management and distribution of oil benefits in the Niger Delta.67

In several oil-producing communities, for example, youth have accused traditional leaders for collaborating with multinational oil companies and local political elites to deprive them of the opportunities to benefit from oil proceeds as equal stakeholders in their communities. ${ }^{68}$ This is because some chiefs are not only on payrolls of oil companies, but they are also entitled to community development contracts, employment and scholarship opportunities. Given these privileges, chiefs in oil-producing communities, most often, resist protestations by youths against the oil companies. Consequently, traditional leaders are increasingly being challenged by local youth who are agitating for the expansion of the political and conversational space, not only for purposes of participation and inclusion in community leadership process, but also for openness.

In some cases, youth have formed and operated parallel leadership structures to chieftaincy institutions as a means of renegotiating and altering their status as observers in order to have a share of oil benefits. Until the recent youth agitation in the Niger Delta, traditional leadership institutions in the region as

66 Lundahl, Mats (1997), 'Inside the Predatory State: The Rationale, Methods, and Economic Consequences of Kleptocratic Regimes'. Nordic Journal of Political Economy, Vol. 24, pp. 31-50; Chayes, Sarah (2014), 'Corruption: The Unrecognized Threat to International Security'. A Paper of the Carnegie Endowment for International Peace (Washington, DC: Carnegie Endowment for International Peace.

${ }^{67}$ UNDP, 2006

${ }^{68}$ Adunbi, Omolade (2011), Oil and the Production of Competing Subjectivities in Nigeria:

'Platforms of Possibilities' and 'Pipelines of Conflict'. African Studies Review, Vol. 54, No. 3. pp $101-120$ 
elsewhere in Nigeria have historically been the prerogative of elders mainly because of age. In fact, in much of Africa, age is perceived to be synonymous with wisdom and to that extent, young people hardly participate in community decision making processes. In places such as Nembe communities in Bayelsa state, traditional leadership institutions have been reformed through a process of dialogue that resulted in constitutional sharing of power between the chiefs and youth. Yet, in some extreme cases such as in Rumuekpe communities in Ikwerre, Rivers state, youth agitation for inclusion has been violently expressed, leading to the sacking of several villages. This intergenerational struggle by youth in the Niger Delta reflects both a desire for inclusion and participation in community leadership processes as well as general dissatisfaction with hierarchies of power, paternalism and patrimonial domination, which youth see as structural barriers to their own socioeconomic and political mobility. ${ }^{69}$

\section{Coercive Leadership Styles and the Dynamics of Oil Conflicts}

Coercion constitutes one of the key elements of power available to a leader, which can be effectively used in some situations to make positive change. ${ }^{70}$ In the Niger Delta the use and reliance on coercive leadership styles by national political leaders to repress any popular agitation perceived to threaten oil extraction in the region has been commonplace. As the Ogoni case amply illustrates, a particular conception of sovereignty and security saw the formation of a special Rivers State Internal Security Task Force code-named Operation Restore Order and Stability in 1994 by the late Sani Abacha. Headed by Major Paul Okontimo, the Rivers State Internal Security Task Force was stationed in Ogoni mainly to protect oil and Shell. The Task Force was sufficiently resourced: militarily by the Nigerian State and financially, by Shell Oil Company ${ }^{71}$ with an implicit mandate to suppress the Ogoni struggle and

${ }^{69}$ Obi, Cyril (2006), 'Youth and Generational Dimensions for Resource Control Struggles in the Niger Delta'. Dakar: Council for the Development of Social Research in Africa (CODESRIA)

${ }^{70}$ French and Raven, 1959

${ }^{71}$ Amusan, Lere (2014), From Operation Law and Order to Operation Restore Hope: Human security crisis in the Niger Delta. In Christopher Lamonica and J. Shola Omotola, eds., Horror in Paradise Frameworks for Understanding the Crises of the Niger Delta Region of Nigeria. North Carolina: Carolina Academic Press 
broadly, any form of local resistance that directly threatens oil flows in the region. ${ }^{72}$

In 1990 Ogoni people had under the umbrella of the Movement for the Survival of Ogoni People (MOSOP) issued a Bill of Rights, demanding for local political autonomy to control its oil resources as a state within the Nigerian federation. Taking advantage of the prevailing world opinion in favour of protecting the environment in the post-Cold War, MOSOP embarked on intensive and effective media campaigns both internationally and locally to mobilise political support against the Nigerian State and Shell for the ecological destruction of Ogoni. By 1993, MOSOP had declared Shell Persona Non Grata in Ogoni and the company subsequently seized operating in the area with attendant loss of oil revenue, the soul of Nigeria's economy.

For Sani Abacha, the Ogoni agitation for the restructuring of Nigeria's defective federal arrangement for political inclusiveness must be contained, not only because of its effects on the national economy, but also because of the fear of the potential spread of the Ogoni ideology to other areas in the Niger Delta and beyond. ${ }^{73}$ Against this background, the non-violent Ogoni struggle for the democratisation of social life in Nigeria was 'securitised' and the Okuntimo-led Rivers State Internal Security Task Force embarked on brutal campaigns of torture, repression and intimidation such as killings, floggings, maiming and rape in Ogoniland with impunity. In fact, Major Paul Okuntimo's impunity in Ogoni was self evident. He boasted that he was professionally trained to kill and he has over 200 ways of killing a human. As the Human Rights Watch (HRW) has noted, about 2000 Ogonis suffered extrajudicial prosecutions by the Security Task Force. ${ }^{74}$ In fact, military personnel attached to the Security Task Force committed ' $71 \%$ of the rape cases' during the Ogoni crisis. ${ }^{75}$ The intimidation and repressive strategy of Sani Abacha culminated in the hanging of nine MOSOP leaders including the writer Ken Saro-Wiwa by the federal government on November 10, 1995.

72 Obi, Cyril (1999), 'Resources, Population and Conflicts: Two African Case Studies'. Africa Development, Vol. XXIV, No. 3 and 4. pp. 47-70

${ }^{73}$ Amusan, (2014)

${ }^{74}$ Human Rights Watch (HRW) (1999), The Price of Oil: Corporate Responsibility and Human Rights Violations in Nigeria's Oil Producing Communities (New York: Human Rights Watch New York)

75 Odoemene, Akachi (2012), 'The Nigerian Armed Forces and Sexual Violence in Ogoniland of The Niger Delta Nigeria, 1990-1999'..Armed Forces \& Society, Vol. 38 No. 2, p. 235 
Similarly, Olusegun Obasanjo's leadership style and response to Niger Delta conflicts were not radically different from that of Sani Abacha. Few months after Obasanjo was elected president in 1999, he ordered military attacks on Odi community because the youths dared to protest against Shell. Odi was a case of outright decimation. The invading soldiers completely razed down the community in the state's attempt to suppress rather than tackle legitimate community grievances. In a ruling in the case instituted by the Odi community against the Federal Government, a Federal High Court in Port Harcourt on February 19, 2013 described the military attacks on Odi as genocidal and ordered the Federal government to pay the sum of N37.6 billion as compensation to the Odi people. Beyond the Odi massacre, Obasanjo also established the Joint Military Taskforce (JTF) in 2003. The structure, composition and operation of the JTF were not different from Abacha's Security Task Force except that its mandate covers the entire Niger Delta. The JTF has been described as an 'army of occupation'. ${ }^{76}$ It is instructive to note that President Shehu Musa Yar'Adua also maintained the JTF repressive structure and had in the context of Operation Restore Hope, invaded the Gbaratu community in 2009 prior to the implementation of the Amnesty Programme. However, as each Nigerian leader became increasingly brutal with limited successes, so the grievances of the people deepened and the escalated.

In a broader sense, therefore, the logic of violent responses to the conflicts by successive national political leaders in Nigeria has created new grievances and the deepening of old ones, and ultimately the emergence of restive youths and a legacy of militancy in the region. Some of contended that the seeming failure of non-violent approach of MOSOP in the 1990s was central to the adoption of counter violence by disaffected youths who felt that violence appears to be the most viable means of gaining attention and obtaining concessions from the Nigerian State. ${ }^{77}$ Asari Dokubo makes this point poignantly in 2005 when he asserts:

'For how long will we talk? How long people had been calling for dialogue with the Nigerian State? The Nigerian State is dead (deaf?) and dumb. Rewane called for dialogue, he was killed. Gani did the

\footnotetext{
${ }^{76}$ Courson, Elias (2011), 'MEND: Political Marginalisation, Repression and Petro-insurgency in the Niger Delta'. African Security, Vol, 4, No. 1, p. 30

77 Tamuno (2011)
} 
same thing, he was chastised. The only language Nigerian State understands is bang, bang, bang because they are dead and dumb'. ${ }^{78}$

\section{Constructive Consenting and Destructive Consenting: The Nature and Implications of followership Styles for oil conflict and Peacebuilding}

The preceding two sections have focused on the exclusionary nature of the leadership process as epitomised in oil control regimes, oil policies and leadership styles. Based on the process theoretical approach adopted in this paper, it is argued here that followership styles/behaviours of the people of the Niger Delta matter in the perpetuation of oil-related conflict. This can be understood within the context of destructive consenting, which complicates the process of sustainable resolution of oil conflict in the region. In an analysis of followership behaviour in the leadership process, Keath Grint distinguishes between 'constructive dissenters' and 'destructive consenters' and highlights their implications for the achievement of a group's goal and group survival. Constructive dissenters are followers who can constructively disagree with a leader when his/her decisions, actions and policies are wrong and offering alternative ideas for achieving the collective goal. ${ }^{79}$ Destructive consenters, on the other hand, are followers who acquiesce, submit or comply almost always with the leader even at their own peril and that of the organization. ${ }^{80}$ In this regard, destructive consenters are ineffective followers, corresponding with what Robert Kelley calls uncritical passive followers. ${ }^{81}$

Broadly, constructive dissenting enables leaders have access to alternative perspectives and ideas that not only enrich the decision-making process, but also engender consensus building and better solutions. Constructive dissenting, thus, creates what Keith Grint calls 'clumsy solutions space' for addressing 'a wicked problem'. ${ }^{82}$ Constructive dissenting and destructive consenting may reflect the nature and quality of followership, for example, the level of awareness of followers and or their enlightened self-interests amongst others. The expression of constructive dissenting and destructive consenting

\footnotetext{
${ }^{78}$ Ibid p.220

${ }^{79}$ Grint (2010)

80 Ibid

81 Kelley, R. (1998), Followership in a Leadership World. In: L. Spears, ed., Insights on Leadership: Service, Stewardship, Spirit and Servant Leadership. Toronto: John Wiley and Sons. ${ }^{82}$ Grint (2010)
} 
behaviour may also be a function of different factors including the changing dynamics of the context, leader's behaviour, lack of trust in the leader, values, ethnic and social identity. For instance, 'the outcomes that stem from a leaderfollower exchange can influence future interactions because they may produce a change in context, in the followers, and/or in the leader'. ${ }^{83}$ It is within this changing dynamics, both in the structural contexts and leaders' behaviour that the dynamics and role of followership in the management of state-society oil relations in the Niger Delta can be meaningfully appreciated.

Local populations in the Niger Delta have responded to the issues of resource control and management, and the distribution of oil-related opportunities in a variety of followership styles including constructive consenting and destructive consenting. Writing of petitions by local communities to express their grievances against the failure of corporate social responsibility in the Niger Delta constitutes early forms of local resistance in the region amongst others. However, the formation of MOSOP in 1990 and the Ijaw youth Council (IYC) in 1998, which issued the Ogoni Bill of Rights and the Kaiama Declaration respectively, represent the most structured expression of community-based constructive dissenting in the Niger Delta. These organisations challenged national leaderships over issues of resource ownership through non-violence, and reinterpreted national sovereignty over oil extraction in the region to include the responsibility to protect, not only MNOCs and oil, but also the people and environment of the region in a more responsible manner. The activities of these groups were, however, securitised by the state; hence the region degenerated into violence. How this happened, has been discussed earlier in relation to MOSOP. Therefore, this section concentrates on destructive consenting behaviour of the people and its implications for sustainable peacebuilding in the region.

The phenomenon of oil theft, particularly, artisanal crude oil refining constitutes destructive consenting in the Niger Delta in some sense. It enjoys considerable level of local sympathies and support that have contributed to its sustenance. Generally, oil theft in the region is a multi-networked activity involving the military institutions and people with strong political connections to the state. Dating back to the 1970s in which refined petroleum products were mainly stolen, oil theft is not entirely new in the region and at present,

83 Pierce and Newstrom (2011), p. 6 
accounts for the loss of 145,000 bpd in Nigeria. ${ }^{84}$ However, local refining of crude oil undertaken by impoverished and unemployed local youths emerged in 2004 and became pervasive in local communities in post-amnesty Niger Delta. Besides the loss of revenue to the state, the crude methods employed in local oil refining have had serious negative implications for the environment, thus compounding the already worsened existing ecological destruction occasioned by the political economy of oil production in the region by MNOCs. Yet, local support of the grassroots has been a critical factor in the effectiveness and thriving of artisanal refining of crude oil in the region.

As the finding of a recent study suggests, most Niger Delta people and local communities where artisanal oil production takes place appear to have turned a blind eye to it because of lingering grievances, perceptions and feelings of alienation from the benefits of the oil economy. ${ }^{85}$ It is argued here that the attitude of the local communities to artisanal oil production constitutes destructive consenting. Local crude oil refining poses a serious threat to the ecology and environment of the region, and therefore, the immediate and longterm economic, social and political survival of the people is at risk. Similarly, during the era of armed insurgency several people and local communities in the region suffered from the downsides of militancy such as rape and kidnapping. Yet, local support, cooperation and sympathies for militancy, which may have been influenced, perhaps, by deeply rooted grievances of the neglect of the Niger Delta people, were central to the survival of insurgency in the region. 86

Furthermore, destructive consenting behaviour in the Niger Delta, akin to what Peter Ekeh calls the 'two publics' 87 is evident in the way indigenes honour and accord recognition to political leaders who have looted public treasury. The two publics reflect the structure of citizenship and nature of citizenship behaviour in post-colonial Africa, which can be best captured within context of the primordial public and civic public. The primordial public

\footnotetext{
${ }^{84}$ Naanen and Tolani (2014), p. 13

85 Ibid

86 Omotola, J. Shola. (2010), 'Liberation Movements and Rising Violence in the Niger Delta: The new Contentious Site of Oil and Environmental Politics'. Studiess in Conflict andTerrorism, Vol 33, Issue 1, pp. 36-54

87 Ekeh, Peter. P. 'Colonialism and the two publics in Africa: A theoretical statement'. Comparative Studies in Society and History, Vol. 17, No1, pp. 91-112
} 
is synonymous with one's community in which citizens perform their duties and obligations with a deep sense of morality and accountability to protect it. But in the civic public, the same citizens engage in all forms of corrupt practices to gain materially from it in order to protect and strengthen the primordial public. In other words, 'the unwritten law of the dialectics is that it is legitimate to rob the civic public in order to strengthen the primordial public'. ${ }^{88}$ The primordial public, is therefore, characterized by morality while the civic public is profoundly amoral.

In the Niger Delta, political leaders who have engaged in primitive accumulation of wealth and embezzlement of oil money to the detriment of collective development in the region, have been conferred with unmerited chieftaincy titles by their own ethnic communities. Paradoxically, it is the same people that will demonise leaders from other ethnic groups who have engaged in similar corrupt practices. A case in point is the 2005 Alamieyeseigha corruption issue. In 2005 Chief D.S.P. Alamieyeseigha, then Governor of Bayelsa state was detained in London on charges of money laundering. Cash of about two million pounds looted from Bayelsa state treasury was found in his home in London. ${ }^{89}$ However, when he disguised as a woman and escaped from London to Nigeria, he was well received and celebrated by majority of Bayelsans and other people in the region. Some described him as a Niger Delta hero. ${ }^{90}$ This is an illustration of the collapse of public morality in post-colonial Nigeria as Peter Ekeh's two publics epitomize. Eke is correct. However, this study sees such behaviour as a failure of effective followership with implications for the reinforcement of corruption, which itself is structural violence in Johan Galtung's distinction between direct and structural violence. ${ }^{91}$

Similarly, although President Jonathan lost in the March 2015 presidential election as the Peoples Democratic Party (PDP) candidate, he secured majority of the votes cast in all the Niger Delta states except Ondo, suggesting a high

88 Ibid p.108

${ }^{89}$ Ajayi, F. (2005), "Madam' Alamieyeseigha, 'Hot mama' - the 'Bride' of the Century; Welcome

'Home'.' Available @ http://nigeriaworld.com/columnist/ajayi/112405.html Retrieved August $\underline{19}, \underline{2014}$

${ }^{90}$ Ajayi (2005)

91 Galtung, Johan (1969), 'Violence, Peace, and Peace Research'. Journal of Peace Research, Vol. 6, No. 3. pp. 167-191 
level of support by the people. Baring political party affiliations, such support constitutes destructive consenting behaviour because Jonathan's priorities in the previous six years in office as president did not connect to the security needs and aspirations of the local populations in the Niger Delta. In other words, there was no sense of mutuality and common purpose between the needs and aspirations of the local people in the Niger Delta and Jonathan's exercise of leadership in many ways. Several factors indicate this. First, apart from establishing a federal University at Etueke, his immediate home town, the Niger Delta did not experience any form of social, institutional and structural change during his tenure as president of Nigeria or any policy response to the Niger Delta question that had direct positive impact on the material conditions of majority of the local people in the region. Second, the construction of the East-West road that links the Niger Delta to other parts of Nigeria, which the Jonathan administration inherited, remains largely uncompleted after six years as president of Nigeria. Third, the four-month half-hearted National Political Conference President Jonathan put in place on March 17, 2014 to proffer solutions to the challenges of Nigeria almost collapsed on the very issue of resource control in the Niger Delta. In fact, the Conference ended without adopting any policy recommendations on resource control, an issue that is so fundamental to the resolution of the Niger Delta question. Fourth, President Jonathan failed to implement the UNEP Report on Ogoni despite the growing threats of environmental insecurity in the area and much of the Niger Delta. A key explanation for the failure to implement the UNEP Report is that the security of the ordinary people in Ogoni as elsewhere in Nigeria does not matter most in the framing of security by political elites. Given this, it was somewhat not surprising that under the watch of President Jonathan the sum of US $\$ 2.1$ billion dollars meant to buy sophisticated weapons to contain Boko Haram in the Northeast of Nigeria was diverted and shared to top members of PDP in order to secure his victory in the 2015 presidential election. Yet, President Goodluck Jonathan had openly declared in several campaign forums in Nigeria that his political ambitions were not worth the blood of any Nigerians. Paradoxically by the end of 2014, not fewer than 6000 people were killed by the Boko Haram terrorist group in the North.

All of the foregoing points speak to the flaws of leader-based understanding of leadership and leader-based solutions. This is because it is immaterial whether President Goodluck Jonathan is from the Niger Delta or not for him to respond to the problems in the region and elsewhere in Nigeria. Afterall, it took 
President Muhammadu Buhari, a northerner less than a year in office to begin the implementation of the UNEP Report on Ogoni. However, the point of emphasis here is that despite the failure of Jonathan to respond to the lingering socio-economic and political issues in the Niger Delta, he still received overwhelming votes from the Niger Delta people in the 2015 presidential election. This was so, not necessarily because of the nature of ethnic politics in Nigeria and ethnic voting patterns as popularly conceived, but more fundamentally, because of the uncritical nature of followership in Nigeria. The expression of such massive support for Goodluck Jonathan tends to suggest that the people of the Niger Delta were willing to tolerate him regardless of his poor performance in office. As some scholars have noted, 'social evil draws not just on those who positively contribute to keeping people down, but also on all the people who are ready to tolerate the thoroughly unacceptable predicaments of millions of fellow human beings'. ${ }^{92}$ What this means is that a proper mix of commitment and independence by followers to the goals of a group provides the most fertile ground for effective followership. ${ }^{93}$ In process conceptions of leadership, what followers do or fail to do is crucial to promoting or undermining leadership effectiveness and the attainment of collective goals.

\section{Conclusion}

Based on the process theoretical explanation of leadership, this paper has explored the nature of leadership and management of oil competing interests in the Niger Delta. The central argument is that oil-related conflicts have persisted in the Niger Delta because of the exclusionary nature of the leadership process in relation to the regulation and management of oil resources in Nigeria. Oil control legislation and policy structures such as the 1969 Petroleum Decree, which seek to comprehensively deprive the Niger Delta people from controlling oil resources as well as engender inequitable distribution of oil revenue, are disincentive to sustainable peace in the Niger Delta.

Furthermore, the adoption of coercive leadership styles by successive Nigerian leaders to protect oil and oil companies in the Niger Delta, notably, Ogoni in

92 Green, Duncan (2012), From Poverty to power: How Active Citizens and Effective States can Change the World (London: Practical Action Publishing Ltd), p. ix

${ }_{93}$ Grint (2010), p. 19 
1995 and Odi in 2009 rather than the people, has paradoxically intensified alienation of the latter from the benefits of oil extraction. This has had the effect of deepening and reinforcing local grievances and the resort to local resistance that is sometimes violently expressed. The dynamics of the use of coercive leadership style was evident in the evolution of armed rebellion in the Niger Delta in post-Ken-Saro-Wiwa execution in 1995. Yet, the logic of followership styles in which leaders in the Niger Delta, who not only loot the economy are easily recognized and given chieftaincy titles, but also are protected by the people reinforce structural violence, thereby complicating peaceful resolution of oil conflicts in the region.

* Kiale Nyiayaana is a Lecturer in the Department of History and Diplomatic Studies, University of Port, Nigeria

\section{BIBLIOGRAPHY}

Abrahamsen, Rita (2013), Introduction: Conflict and security in Africa. In Rita Abrahamsen, ed., Conflict and Security in Africa (Rochester, New York: James Currey

Adunbi, Omolade (2011), 'Oil and the Production of Competing Subjectivities in Nigeria: 'Platforms of Possibilities' and 'Pipelines of Conflict'. African Studies Review, Vol. 54, No. 3. pp 101-120

Ajayi, F. (2005), "Madam' Alamieyeseigha, 'Hot mama' - the 'Bride' of the Century; Welcome 'Home'.' Available @ http://nigeriaworld.com/columnist/ajayi/112405.html Retrieved August 19, $\underline{2014}$.

Ake, Claude (2000), Social Science As Imperialism (Ibadan: Ibadan University Press, 2nd edition)

Alao, Abiodum (2007), Natural Resources and Conflict in Africa: The Tragedy of Endowment (Rochester: University of Rochester Press) 
Alao, Abiodum and Olonisakin, Funmi (2000), 'Economic Fragility and Political Fluidity: Explaining Natural Resources and Conflicts'. International Peacekeeping, Vol. 7, No. 4, pp 23-36

Allport, Floyd Henry (1924), Social Psychology (Boston: Houghton Miffin)

Amusan, Lere (2014), From Operation Law and Order to Operation Restore Hope: Human security crisis in the Niger Delta. In Christopher Lamonica and J. Shola Omotola, eds., Horror in Paradise Frameworks for Understanding the Crises of the Niger Delta Region of Nigeria (North Carolina: Carolina Academic Press)

Andrews, Anne E. (2006), 'Diamond is forever: De Beers, the Kimberely Process, and the Efficacy of Public and Corporate Co-regulatory Initiatives in Securing Regulatory Compliance Note'. South Carolina Journal of International Law and Business, Vol. 2, No. 1

Auty, R.M. (2001), Resource Abundance and Economic Development. Oxford: Oxford University Press

Basedau, Matthias and Wegenast, Tim C. (2009), 'Oil and Diamonds as Causes of Civil War in sub-Saharan Africa: Under What Conditions?' Colombia International, 70, pp. 35-59

Bass, Bennard. M. (1990), Handbook of Leadership (New York: The Free Press)

Berdal, Mats. \& Malone, David M. (2000), Greed and Grievance: Economic Agendas in Civil Wars (Boulder, CO: Lynne Rienner)

Burns, James. M. (1978), Leadership (New York: Harper \& Row)

Cooper, Andrew Fenton and Higgott, Richard A..and Nossal, Kim Richard (1991), 'Bound to follow? Leadership and followership in the Gulf Conflict'. Political Science Quarterly, Vol. 106, No. 3. pp. 391-410

Cartwright, John R. (1983), Political Leadership in Africa (New York: St. Martin's Press) 
Chayes, Sarah. (2014), 'Corruption: The Unrecognized Threat to International Security'. A Paper of the Carnegie Endowment for International Peace. Washington, DC: Carnegie Endowment for International Peace

Collier, Paul. and Anke, Hoeffler (1998), 'On Economic Causes of Civil War'. Oxford Economic Papers, Vol. 50, No. 4, pp. 563-573

Collier, Paul (1999), 'Doing Well out of War'. Paper prepared for Conference on Economic Agendas in Civil Wars, London, April 26-27, pp. 1-16

Collier, Paul and Anke, Hoeffler (2001), 'Greed and Grievance in Civil War' Washington, DC: World Bank

Courson, Elias (2011), 'MEND: Political Marginalisation, Repression and Petroinsurgency in the Niger Delta'. African Security, Vol, 4, No. 1, pp. 20-43

Cramer, C (2002), 'Homo Economicus Goes to War: Methodological Individualism, Rational Choice and the Political Economy of War'. World Development, Vol. 30, No.11. pp. 1845-1865

Davies, R.C. (1942), The Fundamentals of Top Management (New York: Harper)

Diallo, P. (2014), 'Mining, Governance and Stability in Africa: Comparative Case Studies of Guinea, Botswana and Sierra Leone'. Paper presented at the first Annual Conference of the African Leadership Centre's Leadership and Society Series, at the African Leadership Centre, Nairobi, June 23-25

Davies, R.C. (1942), The fundementals of top management. New York: Harper Dunning, Thad (2005)'.Resource Dependence, Economic Performance, and Political Stability'. Journal of Conflict Resolution, Vol. 49, No.4, pp 451-482

Ekeh, Peter. P. (1975), 'Colonialism and the two publics in Africa: A theoretical statement'. Comparative Studies in Society and History, Vol. 17, No1, pp. 91-112

Ejobowah, John Boye (2000), 'Who Owns the Oil? The Politics of Ethnicity In The Niger Delta of Nigeria'. Africa Today, Vol. 47, No. 1. pp. 29-47 
Etekpe, A., Y. Ayotamuno, M. Nwala, Y.E. Jumbo, M.C. and K. Kariboro (2010), eds., Conflict management and resolution in Nigeria: The Niger Delta experience (Port Harcourt: Pearls Publishers)

French, John R. P and Raven, Bertram (1959), The Bases of Social Power. In D. Cartwright, ed., Studies of Social Power. Ann Arbor, MI: University of Michigan, Institute for Social Research

Galtung, Johan (1969), 'Violence, Peace, and Peace Research'. Journal of Peace Research, Vol. 6, No. 3. pp. 167-191

Gormley-Heenan, Cathy (2006), 'Chameleonic Leadership: Towards a New Understanding of Political Leadership During the Northern Ireland Peace Process'. Leadership, Vol.2, No. 53, pp. 53-75

Green, Duncan (2012), From Poverty to power: How active citizens and effective states can change the world. London: Practical Action Publishing Ltd

Grint, Keith (2010), Leadership: A Very Short Introduction (Oxford University Press)

Herbst, J. (2000), 'Economic Incentives, Natural Resources and Conflict in Africa'. Journal of African Economies, Vol. 9, No. 3. pp. 270-290

Human Rights Watch (HRW) (1999), The Price of Oil: Corporate Responsibility and Human Rights Violations in Nigeria's Oil Producing Communities (New York: Human Rights Watch New York)

Ibeanu, Okechukwu (2006), 'Civil Society and Conflict Management in the Niger Delta: Scoping Gaps for Policy and Advocacy'. Cleen Foundation Monograph Series, No. 2

Idemudia, U. (2010), 'The Extractive Industries Transparency Initiative (EITI) in Nigeria: Sifting Rhetoric From Reality'. Perspectives, Report of the Heinrich Böll Foundation, No. 3.10

Ikelegbe, A. (2005), 'The Economy of Conflict in the Oil Rich Niger Delta Region of Nigeria' Nordic Journal of African Studies Vol. 14, No. 2 
Kabemba, C. (2010), 'The Kimberley Process and the Chiadzwa diamonds in Zimbabwe: Challenges and effectiveness'. Perspectives, Report of the Heinrich Böll Foundation, No. 3.10

Kaldor, Mary (1999), New and old wars: Organized violence in a global era. Palo Alto, (CA: Stanford University Press)

Kaldor, Mary (2013), 'In Defence of New Wars'. Stability, Vol. 2, No. 1. pp. 1-16

Karl, Terry Lyn (1997), The Paradox of Plenty: Oil Booms and Petro-States (Berkeley, CA: University of California Press)

Kalyvas, Stathis. N. (2001), 'New' and 'Old' Civil Wars: A Valid Distinction'? World Politics, Vol. 54, No.1. pp. 99-118

Keen, David (1998), The Economic Functions of Violence in Civil wars (Oxford: Oxford University Press)

Kelley, R. (1998), Followership in a Leadership World. In: L. Spears, ed., Insights on Leadership: Service, Stewardship, Spirit and Servant Leadership (Toronto: John Wiley and Sons)

Kirkpatrick, Shelley A and Locke, Edwin A. (1991), 'Leadership: Do Traits Matter'. Academy of Management Executive Vol. 5, Issue 2, pp. 48-60

Kuku, Kingsley (2013), 'Assessing the Dynamics and Sustainability of the Niger Delta Amnesty Programme' A presentation made by Hon. Kingsly Kuku to Nigerians in the Diaspora' (Abuja: Amnesty Office)

Le Billon, Philipe (2001), 'The Political Ecology of War: Natural Resources and Armed Conflicts'. Political Geography, Vol. 20, Issue 5. pp. 561-584

Le Billon, Philippe (2012), Wars of plunder: Conflicts, profits and the politics of resources (New York: Columbia University Press)

Lujala, Paivi (2010), 'The Spoils of Nature: Armed conflict and Rebel Access to Natural Resources', Journal of Peace Research, Vol. 47, No. 1, pp. 15-28 
Lundahl, Mats (1997), 'Inside the Predatory State: The Rationale, Methods, and Economic Consequences of Kleptocratic Regimes'. Nordic Journal of Political Economy, vol. 24, pp. 31-50

Malaquias, A. (2007), Rebels and Robbers: Violence in Post-colonial Angola. Uppsala: Nordiska Afrikainstitutet

Morrison, Kelvin M (2013), (2013) 'Whither the Resource Curse?' Perspectives on Politics, Vol. 11, Issue 4, pp. 1117-1125

Mueller, John (2000), 'The Banality of 'Ethnic War'. 'International Security, Vol. 25, No.1. pp. 42-70

Murphy, Albert J. (1941), 'A Study of the Leadership Process'. American Sociological Review Vol. 6, No. 5, pp. 674-687

Naanen, Ben (1995), 'Oil-producing Minorities and the Restructuring of Nigerian Federalism: The Case of the Ogoni people'. The Journal of Commonwealth \& Comparative Politics, Vol. 33, No. 1, pp. 46-78

Naanen, Ben and Tolani, Patrick (2014), 'Private gain public disaster: Social context of illegal oil bunkering and artisanal refining in the Niger Delta'. Report of the Niger Delta Environment and Relief Foundation (NIDEREF) (Port Harcourt: NIDEREF)

Northouse, Peter.G. (2013), Leadership: Theory and Practice (SAGE: Thousand Oaks, California)

Obi Cyril (1997), 'Globalisation and Local Resistance: The Case of the Ogoni Versus Shell'. New Political Economy, Vol.2 No1. pp. 137-148

Obi, Cyril (1999), 'Resources, Population and Conflicts: Two African Case Studies'. Africa Development, Vol. XXIV, No. 3 and 4. pp. 47-70

Obi, Cyril (2006), 'Youth and Generational Dimensions for Resource Control Struggles in the Niger Delta'. Dakar: Council for the Development of Social Research in Africa (CODESRIA) 
Obi, Cyril (2013), Oil as The 'Curse' of Conflict In Africa: Peering through the Smoke and Mirrors. In Rita Abrahamsen, ed., Conflict and Security in Africa (Rochester, New York: James Currey)

Obi, Cyril (2014), 'Oil and Conflict in Nigeria's Niger Delta Region: Between the Barrel and The Trigger'. The Extractive Industry and. Society, Vol. 1, Issue 1, pp. 147-153

Odoemene, Akachi (2012), 'The Nigerian Armed Forces and Sexual Violence in Ogoniland of The Niger Delta Nigeria, 1990-1999'..Armed Forces \& Society, Vol. 38 No.2, pp. 225-251

Ogundiya, Ilufoye.Sarafa (2011), 'Beyond the Geography of Terrorism and Terror of Geography' Thesis: Corruption and the Development tragedy in the Niger Delta region'. Journal of Developing Societies, Vol. 27, No.1. pp. 57-91

Olonisakin, Funmi (2015), 'Re-Conceptualising Leadership for Effective Peacemaking and Human Security in Africa'. Strategic Review for Southern Africa, (37), No 1, pp. 122-151

Omotola, J. Shola (2010), 'Liberation Movements and Rising Violence in the Niger Delta: The new Contentious Site of Oil and Environmental Politics'. Studiess in Conflict andTerrorism, Vol 33, Issue 1, pp. 36-54

Osaghae, Eghosa. E. (1998), 'Managing Multiple Minority Problems in a Divided Society: The Nigerian Experience'. The Journal of Modern African Studies, Vol, 36, No. 1. pp. 1-24

Peters, Krijn and Richards, Paul (1998), "Why We fight': Voices of Youth Combatants in Sierra Leone', Africa, Vol. 68, No. 2, pp. 183-210

Peters, Thomas J. and Waterman, Robert. H. (1982), In Search of Excellence: Lessons From America's Best-run Companies (New York: Warner Books)

Pierce, J.L. \& Newstrom, J.W. (2011), Leadership and the leadership process (New York: Mcgraw-Hill) 
Read, James H. and Shapiro, Ian (2014), 'Transforming Power Relationships: Leadership, Risk, and Hope'. American Political Science Review, Vol. 108, No. 1.

Rothberg, Robert. I. (2003), 'The Roots of Africa's Leadership Deficit'. Compass: A Journal of Leadership, Vol. 1, No 1, pp. 28-32

Rothberg, Robert. I. (2014), 'The Need for Strengthened Political Leadership'. The ANNALS of the American Academy of Political and Social Science, Vol. 652, No. 1, pp. 238-256

Ross, Michael L (2001), 'Does Oil hinder Democracy?' World Politics, Vol. 53, Issue 3, pp. 325-361

Ross, Michael L (2012), The oil curse: How Petroleum Wealth Shapes the Development of Nations (Princeton: Princeton University Press)

Rosser, A. (2006), 'The Political Economy of the Resource Curse: A Literature Review'. Working Paper 268. Brighton: Institute of Development Studies

Saad-Filho, Alfredo and Weeks, John (2013), 'Curses, Diseases and other Resource Confusions'. Third World Quarterly, Vol. 34, Issue 1, pp. 1-21

Sebudubudu, David and Botlhomilwe, Mokganedi Zara (2012), "The Critical Role of Leadership in Botswana's Development: What Lessons'. Leadership, Vol. 8, No. 1, pp. 29-45

Smirch, Linda and Morgan, Gareth (1982), 'The Management of Meaning'. Journal of Applied Behavioural Science, Vol. 18, No. 3, pp. 257-273

Somerekun, K. (1995), Perspectives on the Nigerian Oil Industry (Lagos: Amkra Books)

Tamuno, Tekena.N. (2011), Oil Wars in the Niger Delta (Ibadan: StirlingHorden Publishers)

Torvik, Ragnar (2002), 'Natural Resources, Rent Seeking, and Welfare'. Journal of Development Economics, Vol. 67, issue 2, pp. 455-470 
United Nations Development Programme (2006), 'Niger Delta United Nations Human Development Report of the United Nations Development Programme'. (UN House Abuja: Nigeria)

United Nations Environment Programme, UNEP Report, (2011), 'Environmental Assessment of Ogoniland' United Nations Environment Programme, Nairobi

Yates, Douglas A. (2012), The Scramble for African Oil: Oppression, Corruption and War for the Control of Africa's Natural Resources (London: Pluto Books) 